\title{
Acta
Biochimica
Polonica
}

Vol. 48 No. 3/2001

$687-698$

QUARTERLY

This work is dedicated to the memory of Professor Jacek Augustyniak

\section{Antioxidative defense to lead stress in subcellular compartments of pea root cells}

\author{
Arleta Małecka ${ }^{1}$, Wiesława Jarmuszkiewicz ${ }^{2}$ and Barbara Tomaszewska ${ }^{1 \bowtie}$ \\ ${ }^{1}$ Department of Biochemistry, ${ }^{2}$ Department of Bioenergetics, Institute of Molecular Biology and \\ Biotechnology, Adam Mickiewicz University, Poznań, Poland
}

Received: 22 January, 2001; revised: 9 May, 2001; accepted: 30 August, 2001

Key words: alternative oxidase, catalase, lead, mitochondria, oxidative stress, peroxisomes, Pisum sativum, superoxide dismutase, superoxide anion

Lead, similar to other heavy metals and abiotic factors, causes many unfavorable changes at the subcellular and molecular levels in plant cells. An increased level of superoxide anion in Pisum sativum root cells treated with $1 \mathrm{mM} \mathrm{Pb}\left(\mathrm{NO}_{3}\right)_{2}$ evidenced oxidative stress conditions. We found increased activities of enzymatic components of the antioxidative system (catalase and superoxide dismutase) in the cytosol, mitochondrial and peroxisomal fractions isolated from root cells of Pisum sativum grown in modified Hoagland medium in the presence of lead ions $(0.5$ or $1 \mathrm{mM})$. Two isoenzyme forms of superoxide dismutase (Cu,Zn-SOD and Mn-SOD) found in different subcellular compartments of pea roots were more active in Pb-treated plants than in control. Increased amount of alternative oxidase accompanied by an increased activity of this enzyme was found in mitochondria isolated from lead-treated roots. These results show that plants storing excessive amounts of lead in roots defend themselves against the harmful oxidative stress caused by this heavy metal.

Plants respond to heavy metal ion stress in different ways including exclusion, chelation, compartmentalization, and expression of stress protein genes. Lead is one of the main sources of environmental pollution. Previous studies have shown that lead inhibits metabolic processes such as nitrogen assimilation, photosynthesis, respiration, water uptake,

\footnotetext{
To whom correspondence should be addressed: Barbara Tomaszewska, Department of Biochemistry, Institute of Molecular Biology and Biotechnology, Adam Mickiewicz University, A. Fredry 10, $61-701$ Poznań, Poland; phone: (48 61) 829 4535; fax: (48 61) 829 4503; e-mail: btomas@main.amu.edu.pl Abbreviations: AOX, alternative oxidase; BSA, bovine serum albumin; CAT, catalase; Mops, 3-( $N$-morpholino)propanesulfonic acid; NBT, nitroblue tetrazolium; PVP, polyvinylpyrrolidone; ROS, reactive oxygen species; $\mathrm{SOD}$, superoxide dismutase; TEMED, $N, N, N^{\prime}, \mathrm{N}^{\prime}$-tetramethylethylenediamide.
} 
and transcription [1-4]. Lead causes two types of unfavorable processes in biological systems. Firstly, lead inactivates several enzymes by binding with their SH-groups [5]. Secondly, lead ions, similarly as those of other heavy metals, can intensify the processes of reactive oxygen species (ROS) production leading to oxidative stress [6-8]. These processes, which destructively affect cell structure and metabolism, are mutually connected and stimulate each other, which may result in a decreased efficiency of oxidation-reduction enzymes or the electron transport system leading to fast production of ROS in the cell [9]. Lead can exert a negative effect on mitochondria by decreasing the number of mitochondrial cristae, which in turn can lower the capacity of oxidative phosphorylation [10]. Legumes treated with lead show lowered activity of nitrogenase in their nodules [11]. By binding to nucleic acids, lead causes aggregation and condensation of chromatin, as well as stabilization of the DNA double helix inhibiting the processes of replication and transcription [3, 12].

An increase in the intracellular (cytosol) concentration of heavy metal ions causes the induction of the synthesis of low-molecular mass peptides with high content of $\mathrm{SH}$ groups, called phytochelatins [5, 13, 14]. The main function of these proteins, called III-class metallothioneins, is to maintain the homeostasis of metals in the plant, i.e. to maintain the concentrations of metals that are necessary for plants (e.g. $\mathrm{Cu}, \mathrm{Zn}$ ) at the most desirable levels and to keep the concentration of other unnecessary metals (e.g. Cd, $\mathrm{Pb}$ ) below the toxic level [5].

Lead, like other heavy metals and other abiotic factors (e.g. electromagnetic radiation, salinity, drought, and xenobiotics), can cause oxidative stress in plant with an accompanying increased ROS production. In extreme cases, when ROS level exceeds the capacity of cell defense mechanisms, structural and functional damage takes place, leading to cell death [15]. The main sites of ROS forma- tion in plant cells are chloroplasts, peroxisomes and mitochondria. One of the most dangerous results of oxidative stress in mitochondria is nonspecific permeability of the inner mitochondrial membrane which results from the formation of channels and peroxidation of membrane phospholipids [16]. As a result, the synthesis of ATP is decreased and the outflow of ions, nucleotides, glutathione and some proteins from mitochondria is increased which directly threatens vital processes in the plant cell [17].

The antioxidative system of the cell includes enzymatic components such as superoxide dismutase (SOD), catalase (CAT), glutathione peroxidase, ascorbic acid peroxidase, and glutathione reductase, as well as nonenzymatic molecules such as ascorbic acid, cysteine, glutathione, $\alpha$-tocopherol, hydroquinone, carotenoids, and polyamines. Superoxide anion radicals produced in different compartments of plant cells are rapidly converted into $\mathrm{H}_{2} \mathrm{O}_{2}$ in a reaction catalyzed by SOD [18, 19]. It is well known that transition heavy metals (e.g. $\mathrm{Cu}, \mathrm{Fe}$ ) catalyze the formation of $\mathrm{OH}$ radicals from $\mathrm{O}_{2}{ }^{-}$in the non-enzymatic Fenton reaction. The molecular mechanisms of $\mathrm{Cd}$ and $\mathrm{Pb}$ toxicity are poorly understood. The protective function of CAT is limited due to its localization mainly in peroxisomes [20]. Antioxidative enzymes occur in cells in many isoforms, often exhibiting different properties [18]. In eukaryotic organisms SOD occurs in three isoforms: mitochondrial Mn-SOD, cytosolic Cu,Zn-SOD and extracellular EC-SOD (Cu,Zn-SOD) [21]. Genes encoding different SOD isoforms respond in a varied way to metabolic and environmental signals [22]. Regulation of the level of antioxidative enzymes gives plants an additional protective ability against oxidative stress [20].

Cyanide-resistant alternative oxidase (AOX) present in plant mitochondria also plays a role in limiting mitochondrial ROS production, thus constituting an additional mechanism of the antioxidative stress defense [23-27]. Ubiquinone is one of the production sites of 
free radicals in the mitochondrial respiratory chain. Electron transport through the alternative pathway (AOX) allows then the cell to maintain respiratory processes and prevents an increase in ubiquinone reduction. Under stress conditions, the activity of the cytochrome pathway decreases and as a consequence ubiquinone reduction increases, intensifying ROS production. Increased activity of AOX could help in maintaining the reduction of respiratory chain components at an appropriate level and diminish the generation of $\mathrm{H}_{2} \mathrm{O}_{2}$. It would be possible then to maintain the production of ROS in balance with the levels of low molecular mass antioxidants and antioxidative enzymes removing free radicals.

Information on the relationship between heavy metal effects and oxidative stress in plants is rather scarce. The aim of our study was to examine at the subcellular level whether $\mathrm{Pb}^{2+}$ ions can lead to increased ROS production and can change the activity of free radical quenching enzymes (SOD, CAT) and AOX in Pisum sativum root cells.

\section{MATERIAL AND METHODS}

Plant material. Three-day old seedlings of pea (Pisum sativum L., cv. Sol.) were grown hydroponically on modified Hoagland medium. In $\mathrm{Pb}$-treated plants, the medium was supplemented with lead ions $(0.5$ or $1 \mathrm{mM}$ $\left.\mathrm{Pb}\left(\mathrm{NO}_{3}\right)_{2}\right)$. Roots were collected after $0,2,8$, 24, 48, 72 and $96 \mathrm{~h}$ of exposition to $\mathrm{Pb}^{2+}$ ions and washed in $10 \mathrm{mM} \mathrm{CaCl}_{2}$ to remove lead accumulated on their surface. Roots for superoxide anion radical detection were frozen in liquid nitrogen and stored at $-70^{\circ} \mathrm{C}$.

Isolation of subcellular fractions. The plant material was homogenized in the isolation buffer containing 5\% BSA, $1 \mathrm{mM}$ EDTA, $1 \%$ PVP, $0.35 \mathrm{M}$ sucrose, and $0.05 \mathrm{M}$ $\mathrm{KH}_{2} \mathrm{PO}_{4} / \mathrm{K}_{2} \mathrm{HPO}_{4}$ buffer ( $\mathrm{pH}$ 7.2). The homogenate was centrifuged for $10 \mathrm{~min}$ at 3000 $\times$ g. Then, the supernatant was centrifuged for $20 \mathrm{~min}$ at $12500 \times \mathrm{g}$. The obtained supernatant was the cytosol fraction. The pellet was gently resuspended in a medium containing $0.3 \mathrm{M}$ mannitol, 0.2\% BSA, $1 \mathrm{mM}$ EDTA, and $20 \mathrm{mM}$ Mops (pH 7.2) and then purified in a continuous gradient formed by $24 \%$ (v/v) Percoll in 0.25 M sucrose, 0.2\% BSA and $20 \mathrm{mM}$ Mops (pH 7.2). The gradient was centrifuged at $40000 \times \boldsymbol{g}$ for $30 \mathrm{~min}$ in fixed angle rotor. Afterwards, the mitochondrial and peroxisomal fractions were carefully collected and washed from Percoll in a 20 -fold volume of a buffer (0.35 M succrose, $20 \mathrm{mM}$ Mops, $\mathrm{pH}$ 7.2). After $30 \mathrm{~min}$ centrifugation at $8000 \times \boldsymbol{g}$, purified mitochondria and peroxisomes were resuspended in the same buffer. Protein was determined according to the Bradford method [28], using the Bio-Rad protein assay.

Electron microscopy. Freshly isolated mitochondria samples were fixed as pellet (sedimented at $13000 \times$ g) overnight in $2.5 \%$ glutaraldehyde in $0.1 \mathrm{M}$ cacodylate buffer $(\mathrm{pH}$ 7.4) and then washed three times for $3 \mathrm{~h}$ each in $2 \%$ osmium tetroxide dissolved in the same medium (at $0^{\circ} \mathrm{C}$ ). After washing in water, the pellet was dehydrated with increasing concentrations of ethanol and acetone and embedded in a mixture of epones. Thin sections were cut with a ultramicrotome and stained with uranyl acetate.

Determination of superoxide anion radical $\left(\mathrm{O}_{2}^{-}\right)$production rate. As it was described in earlier reports [29], whole roots were placed in a test tube and poured over with a solution containing $0.05 \mathrm{M}$ potassium phosphate buffer ( $\mathrm{pH}$ 7.8), 0.05\% nitroblue tetrazolium (NBT), and $10 \mathrm{mM} \mathrm{NaN}$. After 5 min incubation in the dark, $2 \mathrm{ml}$ of the solution was taken up from the tubes and heated at $85^{\circ} \mathrm{C}$ for $15 \mathrm{~min}$. Then, the samples were cooled and absorbance was measured at 580 nm.

Determination of antioxidative enzyme activities. Pea roots were homogenized in a buffer containing $0.05 \mathrm{M}$ potassium phosphate buffer ( $\mathrm{pH} 7.0), 1 \%(\mathrm{v} / \mathrm{v})$ Triton X-100 and $7 \mathrm{mM} \beta$-mercaptoethanol. The homogenate was centrifuged twice for $25 \mathrm{~min}$ at 
$12000 \times \mathbf{g}$. The activity of SOD was assayed by measuring its ability to inhibit the photochemical reduction of NBT, adopting the method of Beauchamp and Fridovich [30]. The reaction mixture contained $13 \mu \mathrm{M}$ riboflavine, $13 \mathrm{mM}$ methionine, $63 \mu \mathrm{M}$ NBT and $0.05 \mathrm{M}$ potassium phosphate buffer $(\mathrm{pH}$ 7.8). After the addition of root homogenate, switching on a UV lamp for 6 min started the reaction. Absorbance at $560 \mathrm{~nm}$ was then measured. The activity of CAT was determined by directly measuring the decomposition of $\mathrm{H}_{2} \mathrm{O}_{2}$ at $240 \mathrm{~nm}$ for $3 \mathrm{~min}$ as described by Aebi [31], in $0.05 \mathrm{M}$ phosphate buffer ( $\mathrm{pH}$ 7.0) containing $5 \mathrm{mM} \mathrm{H} \mathrm{O}_{2}$ and enzyme extract. The activities of both enzymes were also measured in subcellular fractions (in mitochondria and the cytosol - SOD activity, and in peroxisomes and the cytosol - CAT activity) obtained from pea roots treated with 0.5 $\mathrm{mM} \mathrm{Pb}\left(\mathrm{NO}_{3}\right)_{2}$.

Non-denaturating electrophoresis and SOD detection. Non-denaturating electrophoresis in polyacrylamide gel was conducted according to the modified Davis procedure [32]. Samples contained $5 \mu \mathrm{l}$ of $50 \%$ sucrose with $0.1 \%$ bromophenol blue and $50 \mathrm{ml}$ of isolated cell fractions. The stacking gel contained $3 \%$ acrylamide, $10 \%$ bisacrylamide, $40 \mathrm{mM}$ Tris $/ \mathrm{H}_{3} \mathrm{PO}_{4}$ (pH 6.9), 0.015\% ammonium persulphate, $0.0005 \%$ riboflavin phosphate, and $0.1 \%$ TEMED. The resolving gel contained $10 \%$ acrylamide, $1.25 \%$ bisacrylamide, $6 \mathrm{mM}$ Tris/ $\mathrm{HCl}$ ( $\mathrm{pH} 8.48$ ), 0.008\% ammonium persulphate, $0.0003 \%$ riboflavin phosphate, and $0.2 \%$ TEMED. Electrophoresis was conducted in two different buffers (cathode buffer: 63 $\mathrm{mM}$ Tris/HCl, $\mathrm{pH} 7.47$, and anode buffer: 40 $\mathrm{mM}$ Tris/glycine, $\mathrm{pH} 8.89$ ) at 20-30 mA. In order to detect SOD, the gel was washed in $2.45 \mathrm{mM}$ NBT for $20 \mathrm{~min}$, and then incubated for $15 \mathrm{~min}$ in a solution containing $28 \mathrm{mM}$ EDTA, $0.028 \mathrm{mM}$ riboflavin phosphate, and $36 \mathrm{mM}$ phosphate buffer ( $\mathrm{pH}$ 7.8). The gel was exposed to a UV lamp for $7 \mathrm{~min}$ and then washed in bidistilled water.
SDS/PAGE and immunoblotting. Mitochondria corresponding to up to $100 \mu \mathrm{g}$ protein were solubilized in sample buffer (1\% (w/v) SDS, 60 mM Tris/HCl, pH 6.8, 10\% glycerol, 0,004\% bromophenol blue, $1 \mathrm{mM}$ dithiothreitol, and $8 \% \quad \beta$-mercaptoethanol) and boiled for $4 \mathrm{~min}$. Electrophoresis was carried out in a manner similar to that of Laemmli [33] using 5\% polyacrylamide stacking gel and $12.5 \%$ polyacrylamide resolving gel, followed by Western blotting. Bio-Rad prestained low molecular mass markers were used. Antibodies against alternative oxidase proteins of Sauromatum guttatum (generously supplied by Dr. T.E. Elthon) were used at a dilution of $1: 1000$. Alternative oxidase bands were visualized using the Amersham ECL system.

Measurement of mitochondrial respiration. Mitochondrial oxygen uptake was measured with a Clark oxygen electrode at $25^{\circ} \mathrm{C}$ in $1.5 \mathrm{ml}$ of reaction medium $(0.3 \mathrm{M}$ mannitol, $0.2 \% \mathrm{BSA}, 10 \mathrm{mM} \mathrm{KCl}, 5 \mathrm{mM} \mathrm{MgCl}_{2}, 0.05 \mathrm{M}$ potassium phosphate buffer, $\mathrm{pH}$ 7.5) with 1-2 $\mathrm{mg}$ of mitochondrial protein. State 3 respiration (with $1 \mathrm{mM} \mathrm{ADP}$ ) and cyanide-resistant respiration were measured with $10 \mathrm{mM}$ succinate as substrate.

\section{RESULTS}

Figure 1 presents electron microscopy photographs of mitochondrial fractions isolated and purified on a Percoll gradient from pea roots grown for $72 \mathrm{~h}$ in the absence or presence of $0.5 \mathrm{mM} \mathrm{Pb}^{2+}$. Photographs show that both the control and lead-treated mitochondrial fractions are homogenous as most of the mitochondria have intact matrix and membranes, indicating that the isolation procedure did not damage the structure of mitochondria. In the case of the mitochondria isolated from lead-treated roots, dense granules are present inside these organelles. As shown in Fig. 1, there is a clear reduction of the number of mitochondrial cristae in the mitochon- 


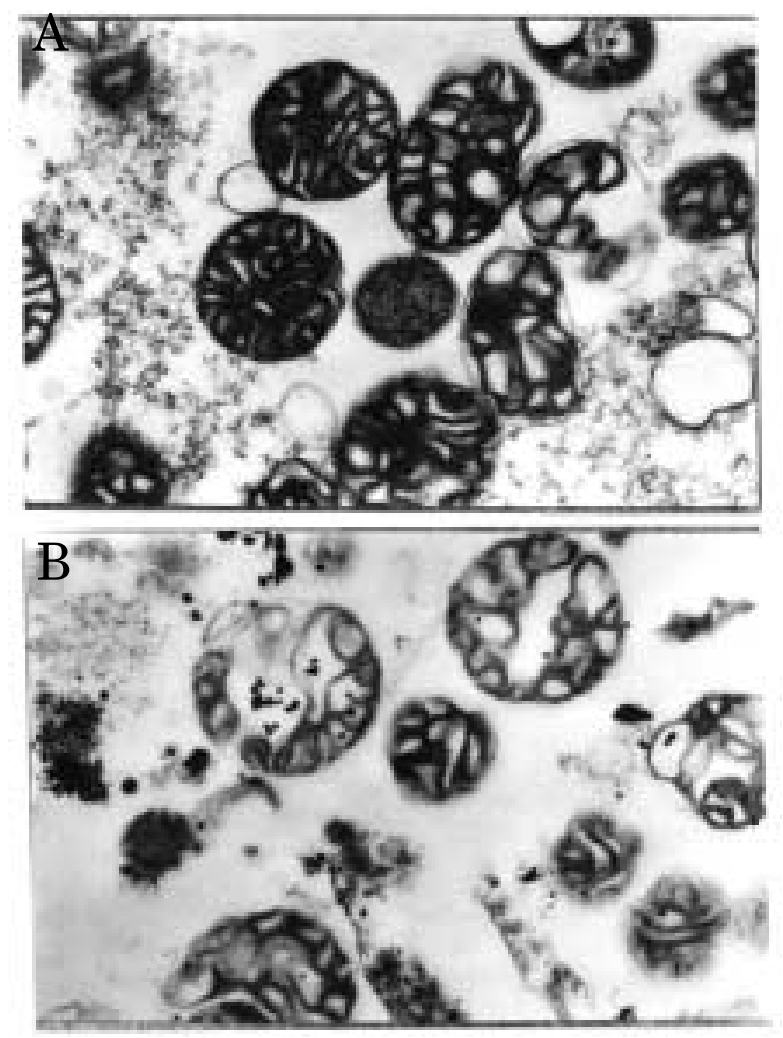

Figure 1. Electron micrographs of pea root mitochondria (A) control and (B) from $0.5 \mathrm{mM}$ $\mathrm{Pb}\left(\mathrm{NO}_{3}\right)_{2}$-treated plants.

dria isolated from plants treated with lead compared to control mitochondria.

Figure 2 shows the effect of $\mathrm{Pb}^{2+}$ on superoxide anion $\left(\mathrm{O}_{2}^{-}\right)$production in pea roots in relation to the cultivation time. At any time of cultivation, lead-stressed roots produced a greater amount of superoxide anion compared with control roots indicating oxidative stress conditions. In lead-treated roots, the amount of superoxide anion generated was significantly increased (almost twice) just after $2 \mathrm{~h}$ of exposition to $1 \mathrm{mM} \mathrm{Pb}\left(\mathrm{NO}_{3}\right)_{2}$ and then it was maintained at a steady level for $48 \mathrm{~h}$. Superoxide anion production started to decrease after $48 \mathrm{~h}$ of lead treatment.

Changes of the activity of two enzymes of the antioxidative system, SOD and CAT, were simultaneously determined in extracts obtained from roots treated with $1 \mathrm{mM} \mathrm{\textrm {Pb } ^ { 2 + }}$ (Figs. 3 and 4). With time of cultivation, a progressive increase in SOD activity (till a 3-fold increase at $24 \mathrm{~h}$ of growing with lead) was observed

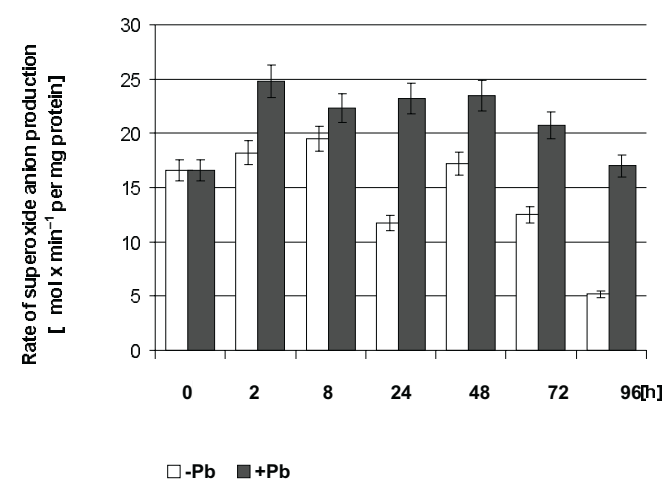

Figure 2. Effect of lead on superoxide anion production in pea roots in relation to cultivation time.

- $\mathrm{Pb}$, control roots; $+\mathrm{Pb}, 1 \mathrm{mM} \mathrm{Pb}\left(\mathrm{NO}_{3}\right)_{2}$-treated roots. Mean values of four independent experiments ( \pm S.D.) are presented.

and then the high activity of the enzyme was maintained. After $96 \mathrm{~h}$, the activity of SOD decreased slightly (by about 17\%). At the same time, the activity of CAT progressively increased, exhibiting the highest value (6 times higher than control) after $72 \mathrm{~h}$ of $\mathrm{Pb}^{2+}$ treatment. After next $24 \mathrm{~h}$, the activity fell by $33 \%$.

When comparing the activity of SOD in subcellular fractions, there was a $15 \%$ increase in SOD activity in the mitochondrial fraction and a $23 \%$ increase in the cytosol fraction in pea roots treated with $0.5 \mathrm{mM} \mathrm{Pb}^{2+}$ for

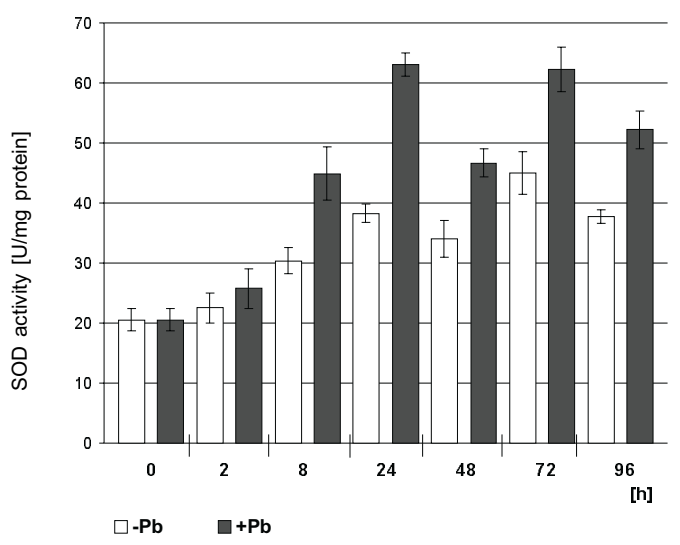

Figure 3. Changes of SOD activity in $1 \mathrm{mM}$ $\mathrm{Pb}\left(\mathrm{NO}_{3}\right)_{2}$-treated pea roots in relation to cultivation time.

Mean values of three independent experiments ( \pm S.D.) are presented. 


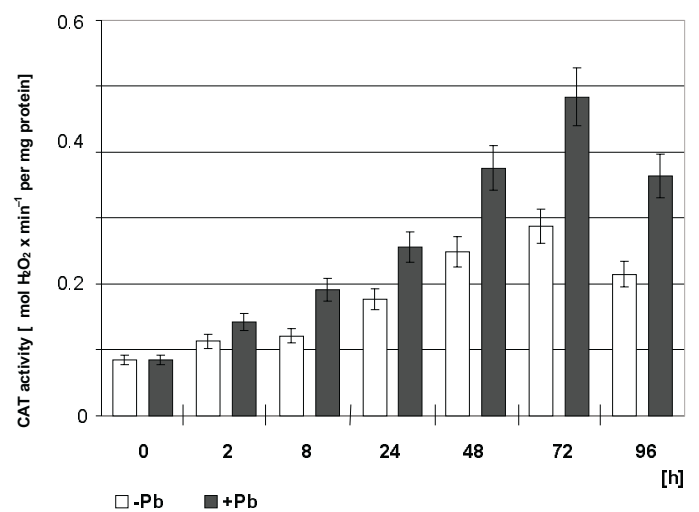

Figure 4. Changes of CAT activity in $1 \mathrm{mM}$ $\mathrm{Pb}\left(\mathrm{NO}_{3}\right)_{2}$-treated pea roots in relation to cultivation time.

Mean values of three independent experiments ( \pm S.D.) are presented.

$72 \mathrm{~h}$ compared with control roots (Fig. 5). Moreover, it is demonstrated that CAT activity in the cytosol fraction increased by $26 \%$ as compared with the cytosol of the control plants, whereas the peroxisomal fraction responded to lead with a $24 \%$ increase in CAT activity (Fig. 6).

When proteins from the subcellular fractions were separated by native electrophoresis and monitored for SOD activity, two isoenzymatic forms localized in different subcellular compartments of Pisum sativum roots were found (Fig. 7). Namely, the cytosol fraction contained two SOD isoforms, of which $\mathrm{Cu}, \mathrm{Zn}-\mathrm{SOD}$ (the form typical for cytosol) was the stronger one, whereas the weaker form visible in the gel, Mn-SOD, was probably derived from mitochondria or peroxisomes damaged during preparation. The main band corresponding to $\mathrm{Cu}, \mathrm{Zn}-\mathrm{SOD}$ is clearly intensified in the cytosol fraction of lead-treated roots indicating an increased activity of this enzyme. The presence of two isoenzymatic forms of SOD represented by bands of weak intensity was observed in the peroxisomal fraction. The $\mathrm{Cu}, \mathrm{Zn}-\mathrm{SOD}$ isoform is more intensive in the peroxisomal fraction from roots treated with lead compared with control. In the pea root mitochondrial fraction, the Mn-SOD form, characteristic of mitochon-

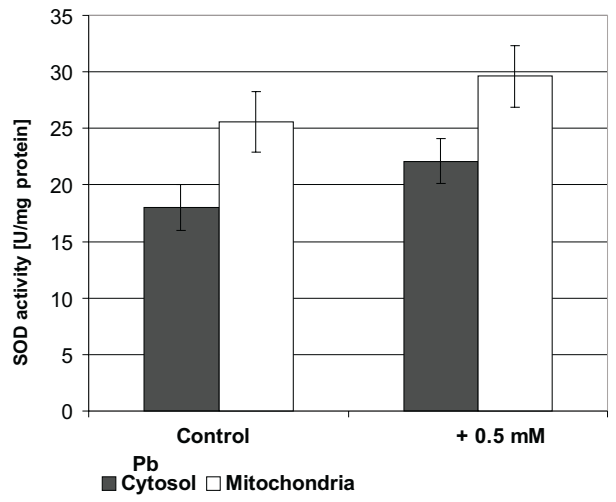

Figure 5. SOD activity in the cytosol and mitochondrial fractions from control and $0.5 \mathrm{mM}$ $\mathrm{Pb}\left(\mathrm{NO}_{3}\right)_{2}$-treated 72-h-old pea roots.

Mean values of three independent experiments $( \pm$ S.D.) are presented.

dria, was detected. When compared with the control, mitochondria from lead-treated roots exhibit a much higher activity of the Mn-SOD.

Mitochondria isolated from roots of control and lead-treated pea plants revealed coupling of electron transport with oxidative phosphorylation. The respiratory control ratio was $1.4 \pm 0.12$ (S.D., $\mathrm{n}=3$ ) and $1.2 \pm 0.09$ (S.D., $\mathrm{n}=$ 3) for mitochondria isolated from control and lead-treated plants, respectively. Measurements of the uninhibited state 3 respiration (mainly representing the cytochrome pathway-mediated respiration) and the cyanide-resistant AOX-mediated respiration al-

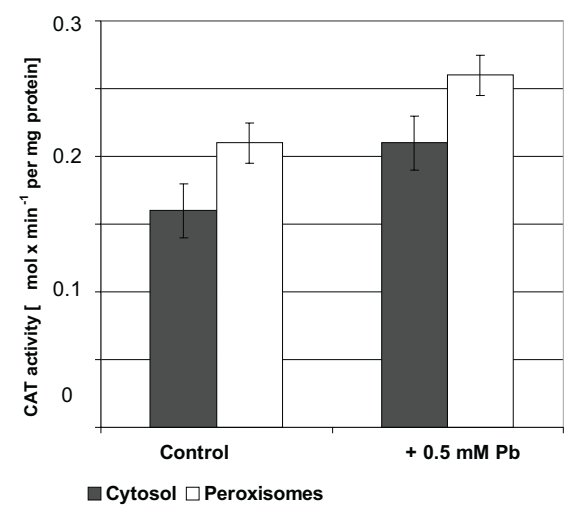

Figure 6. CAT activity in the cytosol and peroxisomal fractions from control and $0.5 \mathrm{mM}$ $\mathrm{Pb}\left(\mathrm{NO}_{3}\right)_{2}$-treated 72-h-old pea roots.

Mean values of four independent experiments ( \pm S.D.) are presented. 


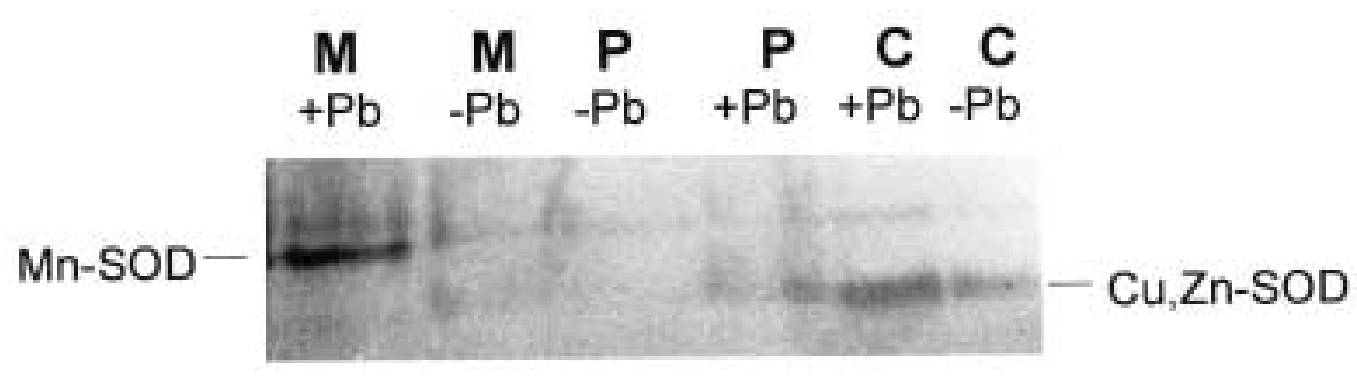

Figure 7. Isoenzyme patern of SOD in the mitochondrial (M), peroxisomal (P), and cytosol (C) fractions of control and $0.5 \mathrm{mM} \mathrm{Pb}\left(\mathrm{NO}_{3}\right)_{2}$-treated 72-h-old pea roots.

Subcellular fraction samples $(100 \mu \mathrm{g})$ were electrophoresed on non-denaturating polyacrylamide gel and the isoenzymes (Mn-SOD and $\mathrm{Cu}, \mathrm{Zn}-\mathrm{SOD})$ were visualized as described under Materials and Methods.

low an estimation of the influence of $0.5 \mathrm{mM}$ $\mathrm{Pb}^{2+}$ ions (during $72 \mathrm{~h}$ of cultivation) on both mitochondrial respiratory pathways in Pisum sativum roots. As shown in Table 1, lead-treatment had no effect on the total uninhibited mitochondrial respiration, whereas it caused a 3 -fold increase in CN-resistant respiration. Immunodetection of the AOX protein showed that the amount of $36 \mathrm{kDa} \mathrm{AOX}$ protein increased markedly in the mitochondria of pea roots grown in the presence of $0.5 \mathrm{mM} \mathrm{\textrm {Pb } ^ { 2 + }}$ for $72 \mathrm{~h}$ compared with control untreated roots (Fig. 8).

\section{DISCUSSION}

The destructive effects of lead are visible at the molecular and cellular levels as well as at the level of the whole plant [34-37]. Roots are especially endangered by the toxic lead effect, because they first have contact with the metal and they are organs where $70-95 \%$ of the lead is accumulated [38]. As shown previously [38], pea (Pisum sativum) is a plant with a medium constitutive tolerance to $\mathrm{Pb}^{2+}$ when analyzed by means of the tolerance index [39]. Electron microscopy photographs (Fig. 1) show that mitochondria from lead-treated plants reveal the presence of dense granules and a reduction of the number of mitochondrial cristae in comparison with control mitochondria. Similar dense granules were local-
Table 1. Uninhibited respiration and CN-resistant respiration in mitochondria isolated from 72-h-old pea roots treated with 0 or $0.5 \mathrm{mM}$ $\mathrm{Pb}\left(\mathrm{NO}_{3}\right)_{2}$.

Values of respiratory rates with $10 \mathrm{mM}$ succinate as substrate in state 3 respiration (+ $1 \mathrm{mM} \mathrm{ADP})$ and in the presence of $1 \mathrm{mM} \mathrm{KCN}$ are in $\mathrm{nmol} \mathrm{O}_{2} \cdot \mathrm{min}^{-1}$ per $\mathrm{mg}$ protein. Data are mean values \pm S.D. of determinations from three separate mitochondria prepatations.

\begin{tabular}{lcc}
\hline & $\mathrm{Pb}\left(\mathrm{NO}_{3}\right)_{2}$ concentration $(\mathrm{mM})$ \\
\hline Conditions & 0 & 0.5 \\
\hline State 3 & $131 \pm 11$ & $138 \pm 7$ \\
+ KCN & $26 \pm 8$ & $73 \pm 5$ \\
\hline
\end{tabular}

ized in mitochondria of Lemna minor roots, which after a thorough X-ray analysis turned out to be granules of lead salts [40], and in maize roots [10] treated with $\mathrm{Pb}^{2+}$. On the other hand, the reduction of the number of

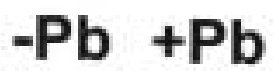

\section{$36 \mathrm{kDa}-$}

Figure 8. Immunoblot of AOX protein in mitochondria isolated from control $(-\mathrm{Pb})$ and $0.5 \mathrm{mM}$ $\mathrm{Pb}\left(\mathrm{NO}_{3}\right)_{2}$-treated $(+\mathrm{Pb})$ 72-h-old pea root.

An immunoblot from 12.5\% SDS/PAGE gel probed for the AOX protein is shown. Mitochondrial protein $150 \mu \mathrm{g}$ was loaded in both lanes. 
cristae in the mitochondria of plants exposed to lead can lead to a decrease in the phosphorylation capacity, as it was found in mitochondria of yellow lupin roots [41].

As shown in Fig. 2, the exposition of pea roots to lead resulted in an increased superoxide anion production. This increase probably intensified the activity of the antioxidative system (Figs. 3 and 4), which leads to a subsequent decrease in the production of $\mathrm{O}_{2}^{-}$following a $48-\mathrm{h} \mathrm{Pb}^{2+}$ exposition. The increased generation of ROS in other plants exposed to heavy metals has been observed, e.g. in Cd-stressed potato tubers [9, 42], in roots of lupin seedlings treated with $\mathrm{Cu}^{2+}, \mathrm{Cd}^{2+}$ or $\mathrm{Pb}^{2+}$ [43] and in Brassica juncea treated with $\mathrm{Zn}^{2+}$ ions [6]. Pisum sativum roots contain an endogenic pool of thiol compounds such as cysteine, glutathione and homoglutathione which are able to chelate lead and, simultaneously, they are low-molecular antioxidants of plant cells [44]. As shown previously [38], an increase in $\mathrm{O}_{2}^{-}$level during the first two hours of lead treatment of pea roots was accompanied by a decrease in cysteine (by $92 \%$ ) and an increase in glutathione (by 88\%) concentration. However, after longer lead exposition the level of both antioxidants was decreased. Thus, in pea roots, the disturbed oxidation-reduction balance caused by a high level of ROS generation and the decreased level of low-molecular antioxidants (thus the balance shifted to the oxidation reactions) indicate the oxidative stress conditions.

Unfavorable changes caused by ROS can be prevented by the defense mechanism of plants, i.e. the antioxidative system, which is composed not only of the low-molecular components but also of enzymatic components such as SOD, CAT, peroxidase and AOX.

Our results demonstrate that prolonged stress induced by lead ions results in the activation of both antioxidative enzymes, SOD and CAT, in extracts from Pisum sativum root tissues (Figs. 3 and 4). A greater activity of the enzymatic components of the antioxidative system indicating stress conditions was also found in subcellular compartments (Figs. 5-7). An increased activity of CAT was observed in the cytosol and peroxisomes, whereas an increased activity of SOD was observed in the cytosol (Cu,Zn-SOD) and mitochondria (Mn-SOD). The correlation between the SOD activity level and the heavy metal stress effect depends on the plant species and the type of the metal. An increase in SOD activity was observed in extracts of lupin roots treated with lead and copper ions [45] and in extracts from leaves of Helianthus annus $\mathrm{L}$. seedlings after 12 -h treatment with $\mathrm{Cu}^{2+}$ ions [46]. In experiments on a prolonged effect of heavy metals on SOD activity in such plants as yellow lupin, soybean and pea many authors observed an increase in the activity of this enzyme after $48 \mathrm{~h}$ of $\mathrm{Zn}^{2+}, \mathrm{Mn}^{2+}, \mathrm{Cu}^{2+}$, $\mathrm{Al}^{3+}$ and $\mathrm{Pb}^{2+}$ treatment $[45,47,48]$. Other authors, on the other hand, observed a decrease in the activity of this enzyme during first $10 \mathrm{~h}$ of stress in tissues of potato tubers treated with $\mathrm{Cd}^{2+}$, which was followed by an activity increase afterwards [9]. $\mathrm{Cd}^{2+}$ ions were shown to decrease SOD and CAT activities in seedlings of Phaseolus vulgaris [49], whereas in other plants they stimulated mitochondrial Mn-SOD activity and chloroplast Fe-SOD activity [7]. The observed changes in SOD activity are the combined result of enzyme inactivation caused by metal ions and SOD synthesis [9]. Therefore, it seems that both the degree of enzyme inactivation and the induced level of its synthesis are important factors of plant tolerance. In the case of CAT, another important enzymatic component of the antioxidative system, changes in activity depend on plant species and heavy metal type. A decrease in CAT activity was observed, e.g. in seedlings of Phaseolus vulgaris treated with $\mathrm{Cd}^{2+}$ ions for a period of 3-6 days [49] and in oat seedlings treated for $24 \mathrm{~h}$ with $\mathrm{Cu}^{2+}$ ions [50], while an increase was observed in wheat seedlings treated with $\mathrm{Al}^{3+}$ ions [51].

Nowadays, it is thought that the mitochondrial antioxidative system includes also the al- 
ternative cyanide-resistant oxidase (AOX) that can participate in the lowering of ROS generation [23-27]. As shown in Table 1, the increased CN-resistant AOX-mediated respiration was found in mitochondria isolated from lead-treated roots. An increased AOX activity caused by heavy metals has been previously observed in some plant species. For example, in mitochondria from potato tubers, non-phosphorylating AOX-mediated respiration was increased under cadmium stress while the membrane potential and the protonmotive force were decreased indicating a slow-down of the cytochrome pathway activity [52]. The significantly increased activity of AOX in the presence of cyanide in mitochondria from lead-treated pea roots suggests that this non-phosphorylating pathway could have increased participation in state 3 respiration (Table 1). The increased amount of AOX in mitochondria isolated from roots of pea plants exposed to lead (Fig. 8) indicates that leadstressed pea root cells clearly up-regulated the level of the AOX protein in mitochondria, which could be correlated with the considerable increase in the CN-resistant respiratory activity. Thus, in Pisum sativum roots under oxidative stress conditions caused by exposure to lead, the increased activity of AOX accompanied by significantly larger amounts of the protein could more efficiently limit harmful ROS production. The increased amount of the AOX protein has been observed under stress conditions (i.e. cold exposure, inhibition of the cytochrome pathway, salt stress) in other plants [24, 25]. In mitochondria isolated from petunia cells treated with $\mathrm{H}_{2} \mathrm{O}_{2}$, a greater amount of the AOX protein was observed [53]. This suggests that induction of AOX synthesis and enzyme activation occur under oxidative stress conditions. On the other hand, it was also shown that inhibition of AOX stimulates $\mathrm{H}_{2} \mathrm{O}_{2}$ production in plant mitochondria [26]. The hypothesis that AOX in plant mitochondria functions as a mechanism that decreases the formation of ROS produced during respiratory electron transport was confirmed by Maxwell et al. [27]. So far, the direct transfer pathway of the signal leading to the induction of AOX gene expression in plant mitochondria has not been identified. It is thought that it may be salicylic acid whose amount increases in thermogenic plants right before the AOX activity reaches its maximum [54]. About $2 \%$ of the oxygen used up by mitochondria undergoes a monoelectron change leading to $\mathrm{H}_{2} \mathrm{O}_{2}$ production, especially between complex I and II of the mitochondrial respiratory chain $[15,54]$. We have demonstrate here that $\mathrm{Pb}^{2+}$ ions penetrate mitochondria of Pisum sativum root cells, which could lead to oxidative stress connected with intensified superoxide (thereby $\mathrm{H}_{2} \mathrm{O}_{2}$ ) production. Therefore, under these conditions mitochondria could use the antioxidative system including mitochondrial Mn-SOD as well as AOX. Our results confirm that the activities of these mitochondrial enzymes are induced under oxidative stress caused by lead.

In conclusion, our results indicate that exposition of Pisum sativum roots to lead results in an increased production of superoxide anion and thereby to oxidative stress conditions. They clearly demonstrate that in Pisum sativum roots lead, like other heavy metals, induces specific responses from the plant antioxidant defense system including the increased activity of SOD and CAT in respective subcellular compartments and the increased activity of mitochondrial AOX. Since plants are more often used nowadays for phytoremediation of soil and water contaminated with heavy metals it is of utmost importance to understand the effect of lead on plants, their tolerance level and defense mechanisms.

\section{R E F E R E N C E S}

1. Burzyński, M. (1988) The uptake and accumulation of phosphorus and nitrates and the activity of nitrate reductase in cucumber seedlings. Acta Soc. Bot. Pol. 57, 349-359. 
2. Krupa, Z., Quist, G. \& Huner, N.P.A. (1993) The effects of cadmium on photosyntesis of Phaseolus vulgaris - a fluoroscence analysis. Physiol. Plant. 88, 626-630.

3. Kurepa, J., Van Montagu, M. \& Inze, D. (1997) Expression of sodCp and sodB genes in Nicotiana tabacum: Effects of light and copper excess. J. Exp. Bot. 48, 2007-2014.

4. Boussama, N., Ouariti, A., Suzuki, A. \& Ghorbal, M.H. (1999) Cd-stress on nitrogen assimilation. J. Plant Physiol. 155, 310-317.

5. Rauser, W.R. (1995) Phytochelatins and related peptides, structure, biosynthesis and function. Plant Physiol. 109, 1141-1149.

6. Prasad, K.V.S.K., Paradha Saradhi, P. \& Sharmila, P. (1999) Concerted action of antioxidant enzymes and curtailed growth under zinc toxicity in Brassica juncea. Environ. Exp. Botany 42, 1-10.

7. Clijsters, A., Cuypers, A. \& Vangronsveld, J. (1999) Physiological responses to heavy metals in higher plants. Defence against oxidative stress. Z. Naturforsch. 54c, 730-734.

8. Cuypers, A., Vangronsveld, J. \& Clijsters, H. (1999) The chemical behaviour of heavy metals plays a prominent role in the induction of oxidative stress. Free Radical Res. 31, 539-543.

9. Stroiński, A. \& Kozłowska, M. (1997) Cadmium-induced oxidative stress in potato tuber. Acta Soc. Bot. Pol. 66, 189-195.

10. Bittel, J.E., Koeppe, D.E. \& Miller, R.J. (1974) Sorption of heavy metal cations by corn mitochondria and the effects on electron and energy transfer reactions. Physiol. Plant. 30, 226-230.

11. Porter, J.R. \& Sheridon, R.P. (1981) Inhibition of nitrogen fixation in alfalfa by arsenate, heavy metals, fluoride and simulated acid rain. Plant Physiol. 68, 143-148.
12. Valle, B.L. \& Ulmer, D.D. (1972) Biochemical effects of mercury, cadmium and lead. Annu. Rev. Biochem. 41, 91-129.

13. Grill, E., Winnacker, E.L. \& Zenk, M.H. (1985) Phytochelatins: The principal heavy-metal complexing peptides of higher plants. Science 230, 674-676.

14. Zenk, M.H. (1996) Heavy metal detoxification in higher plants - a review. Gene 179, 21-30.

15. Raha, S. \& Robinson, B.H. (2000) Mitochondria, oxygen free radicals, disease and ageing. Trends Biochem. Sci. 25, 502-508.

16. Pompella, J.G., Romani, A., Benedetti, A. \& Comport, M. (1991) Loss of membrane protein thiols and lipid peroxidation in allyl alcohol hepatotoxicity. Biochem. Pharmacol. 41, 1255-1259.

17. Inoue, T., Yosida, Y., Nishimura, M., Kurosawa, K. \& Tagawa, K. (1993) $\mathrm{Ca}^{2+}$-induced, phospholipase-independent injury during reoxygenation of anoxic mitochondria. Biochim. Biophys. Acta 1140, 313-320.

18. Noctor, G. \& Foyer, Ch.H. (1998) Ascorbate and glutathione: Keeping active oxygen under control. Annu. Rev. Plant Physiol. Plant Mol. Biol. 49, 249-279.

19. Gupta, M., Cuypers, A., Vangronsveld, J. \& Clijsters, H. (1999) Copper affects the enzymes of the ascorbate-glutathione cycle and its related metabolites in the roots of Phaseolus vulgaris. Physiol. Plant. 106, 262- 267.

20. Foyer, C.H., Descourvieres, P. \& Kunert, K.J. (1994) Protection against oxygen radicals: An important defence mechanism studied in transgenic plants. Plant Cell Environ. 17, $507-523$.

21. Scandalios, J.G. (1993) Oxygen stress and superoxide dismutases. Plant Physiol. 101, 7-12.

22. Alscher, R.G. (1997) Reactive oxygen species and antioxidants: Relationships in green cells. Physiol. Plant. 100, 224-234. 
23. Purvis, A.C. \& Shewfelt, R.L. (1993) Does the alternative pathway ameliorate chilling injury in sensitive plants tissues? Physiol. Plant. 88, 712-718.

24. Purvis, A.C. (1997) Role of the alternative oxidase in limiting superoxide production by plant mitochondria. Physiol. Plant. 100, 165-170.

25. Wagner, A.M. \& Moore, A.L. (1997) Structure and function of the plant alternative oxidase: Its role in the oxygen defence mechanism. Biosci. Rep. 17, 319-333.

26. Popov, V.N., Simonian, R.A., Skulachev, V.P. \& Starcov, A.A. (1997) Inhibition of the alternative oxidase stimulates $\mathrm{H}_{2} \mathrm{O}_{2}$ production in plant mitochondria. FEBS Lett. 415, 87-90.

27. Maxwell, D.P., Wang, Y. \& McIntosh, L. (1999) The alternative oxidase lowers mitochondrial reactive oxygen production in plant cells. Proc. Natl. Acad. Sci. U.S.A. 96, 8271-8276.

28. Bradford, M.M. (1976) A rapid and sensitive method for the quantitation of microgram quantities of protein utilizing the principle of protein-dye binding. Anal. Biochem. 72, 248-254.

29. Doke, N. (1983) Involvement of superoxide anion generation in the hypersensitive response of potato tuber tissues to infection with an incompatible race of Phytophthora infestans and to the hyphal wall components. Physiol. Plant Pathol. 23, 345-357.

30. Beauchamp, C. \& Fridovich, J. (1971) Superoxide dismutase: Improved assays and an assay applicable to acrylamide gels. Anal. Biochem. 44, 276-287.

31. Aebi, H.E. (1983) Catalase; in Methods of Enzymatic Analyses (Bergmeyer, H.U., ed.) vol. 3, pp. 273-282, Verlag Chemie, Weinheim.

32. Davis, B.J. (1964) Disc electrophoresis: II. Method and application to human serum proteins. Ann. N.Y. Acad. Sci. 121, 404-427.
33. Laemmli, U.K. (1970) Cleavage of structural proteins during the assembly of the head of bacteriophage T4. Nature 227, 680-685.

34. Wierzbicka, M. (1987) Lead translocation and localization in Allium cepa roots. Can. J. Bot. 65, 1851-1860.

35. Wierzbicka, M. (1988) Mitotic disturbances induced by low doses of inorganic lead. Caryologia 41, 143-160.

36. Woźny, A. \& Jerczyńska, E. (1991) The effect of lead on early stages of Phaseolus vulgaris L. growth in in vitro conditions. Biol. Plant. 33, $32-39$.

37. Przymusiński, R., Spychała, M. \& Gwóźdź, E.A. (1991) Inorganic lead changes growth and polypeptide pattern of lupin roots. Biochem. Physiol. Pflanzen 187, 51-57.

38. Piechalak, A., Tomaszewska, B., Barałkiewicz, D. \& Małecka, A. (2001) Accumulation and detoxification of lead ions in legumes. Phytochemistry, in press.

39. Willkins, D.A. (1957) A technique for the measurement of lead tolerance in plants. Nature 180, 37-38.

40. Samardakiewicz, S. (2000) Structural and functional effects of lead on plant roots. Ph.D. Dissertation, Adam Mickiewicz University in Poznan (in Polish).

41. Woźny, A. (1995) Lead in plant cells. Sorus, Poznan (in Polish).

42. Stroiński, A. \& Zielezińska, M. (1997) Cadmium effect on hydrogen peroxide, glutathione and phytochelatins levels in potato tuber. Acta Physiol. Plant. 19, 127-136.

43. Rucińska, R., Tukendorf, A., Stroiński, A. \& Gwóźdź, E.A. (1997) Phytochelatins and antioxidant enzymes in lupin roots exposed to heavy metals. Biol. Bull. 34, 50-51.

44. Noctor, G., Arisi, A.C.M., Jouanin, L., Kunert, K.J., Rennenberg, H. \& Foyer, Ch.H. (1998) Glutathione: Biosynthesis, metabolism and re- 
lationship to stress tolerance explored in transformed plants. J. Exp. Bot. 49, 623-647.

45. Przymusiński, R., Rucińska, R. \& Gwóźdź, E.A. (1995) The stress-stimulated $16 \mathrm{kDa}$ polypeptide from lupin roots has properties of cytosolic $\mathrm{Cu} / \mathrm{Zn}$-superoxide dismutase. Environ. Exp. Bot. 35, 485-495.

46. Gallego, S.M., Benavides, M.P. \& Tomaro, M.L. (1996) Effect of heavy metal ion excess on sunflower leaves: Evidence for involvement of oxidative stress. Plant Sci. 121, 151-159.

47. Rio, L.A. del, Sandalio, L.M., Yanez, J. \& Gomez, M. (1985) Induction of a manganese-containing superoxide dismutase in leaves of Pisum sativum L. by high nutrient levels of zinc and manganese. J. Inorg. Biochem. 24, 25-34.

48. Cakmak, I. \& Horst, W.J. (1991) Effect of aluminium on lipid peroxidation, superoxide dismutase, catalase and peroxide activities in root tips of soybean (Glycine max). Physiol. Plant. 8, 463-468.

49. Somashekaraiah, B.V., Padmaja, K. \& Prasad, A.R.K. (1992) Phytotoxity of cadmium ions on germinating seedlings of mung bean (Pha- seolus vulgaris). Involvement of lipid peroxides in chlorophyll degradation. Physiol. Plant. 85, 85-89.

50.Luna, C.M., Gonzales, C.A. \& Trippi, V.S. (1994) Oxidative damage caused by an excess of copper in oat leaves. Plant Cell Physiol. 35, 11-45.

51. Cakmak, I., Strbac, D. \& Marschner, H. (1993) Activities of hydrogen peroxide scavenging enzymes in germinating wheat seeds. J. Exp. Bot. 44, 127-132.

52. Kesseler, A. \& Brand, D. (1995) The mechanism of the stimulation of state 4 respiration by cadmium in potato tuber (Solanum tuberosum) mitochondria. Plant Physiol. Biochem. 33, 519-528.

53. Wagner, A.M. (1995) A role for active oxygen species as second messengers in the induction of alternative oxidase gene expression in Petunia hybrida cells. FEBS Lett. 368, 339-342.

54. Vanlerberghe, G.C. \& McIntosh, L. (1997) Alternative oxidase: From gene to function. Annu. Rev. Plant Physiol. Mol. Biol. 48, 703734. 